\title{
Alternatives to Chemical Control of Insect Pests
}

\author{
Eric J. Rebek ${ }^{1}$, Steven D. Frank ${ }^{2}$, \\ Tom A. Royer ${ }^{1}$ and Carlos E. Bográn ${ }^{3}$ \\ ${ }^{1}$ Oklahoma State University \\ ${ }^{2}$ North Carolina State University \\ ${ }^{3}$ Texas AEM University \\ United States of America
}

\section{Introduction}

In 2011, practitioners and advocates of Integrated Pest Management (IPM) find themselves addressing agricultural, societal, and political pressures worldwide resulting from human population growth. This growth brings simultaneous burdens of sustaining a steady food supply; these include preventing losses from pests, dealing with increased human global travel, which in turn intensifies opportunities for the establishment of non-endemic pests into new ecosystems, and addressing global climate change that potentially will shift pest distributions into new areas. Concurrently, societal concerns about pesticide presence in our food and environment have resulted in political and economic pressures to reduce chemical pesticide use, or at a minimum, emphasize the development and use of products that are less toxic and more environmentally safe. These concerns drive the discovery and development of alternatives to chemical control of plant pathogens, weeds, and insect pests. The term Integrated Pest Management has, more often than not, been identified with entomologists. Stern et al. (1959) first used the term "integrated control" to describe the potential for integration of chemical and biological control tactics. Yet from a historical view, the concept of integrating chemical control with other tactics was proposed much earlier (Hoskins et al., 1939). Furthermore, integrating multiple non-chemical tactics to control a pest has been a cornerstone of the discipline of plant pathology throughout much of its early history (Jacobsen, 1997). In fact, because plant pathologists did not have an array of corrective pesticides available to them, the development and integration of control methods that emphasized non-pesticide controls (e.g., genetic host resistance, crop rotations, tillage, and plant sanitation) for plant diseases was a necessity, not simply an option for plant disease management. In contrast, entomologists and weed scientists were more insulated from that necessity due to the availability of relatively inexpensive pesticides to correct a problem.

Several events stimulated the necessity for developing IPM programs in entomology, including those that emphasized development of non-chemical methods of insect control (e.g., cultural, biological, and physical control described herein). The chlorinated hydrocarbon, DDT, had been used for control of various insects since the 1950's. Soon after its use began, some pests began to develop resistance to DDT, including house flies, mosquitos, bed bugs, and body lice (Metcalf, 1989). The publication of Rachel Carson's book, "Silent Spring", in 1962 also generated public concern. Carson highlighted the negative 
impacts that widespread use of insecticides could have on the environment and ultimately, human health. What followed was a passionate global reaction that generated intense economic and political pressure to regulate pesticide use and monitor their relative impacts on biological systems. In the United States, the Environmental Protection Agency was created and charged with regulating the registration of all pesticides through the Federal Insecticide, Fungicide and Rodenticide Act (as amended in 1972). Concerns over pesticide use also stimulated the political thrust necessary for support of IPM programs. In the United States and worldwide, IPM flourished in the following three decades and was adopted as policy by various governments (Kogan, 1998).

Today, IPM has attained many successes but fallen short on some issues. Due to the awareness and biological understanding of how insecticide resistance develops, and because insecticides are so expensive to develop, in 1984 the manufacturers of insecticides created the Insecticide Resistance Action Committee (IRAC) to encourage the responsible use of their products in a manner that minimizes the risk of insecticide in target pest populations (IRAC, 2010). New calls have been made for changing the direction of IPM in response to waning political support for funding IPM programs. Frisbie \& Smith (1989) coined the term "biologically intensive" IPM, which involves reliance on ecological methods of control based on knowledge of a pest's biology. Benbrook et al. (1996) promoted the idea of moving IPM along a continuum from simple to complex, or "biointensive". The National Research Council officially introduced the term, "Ecologically Based Pest Management", calling for a new paradigm for IPM in the 21st Century (National Research Council, 1996); eight years earlier, however, Horn (1988) outlined how principles of insect ecology could be incorporated into insect pest management strategies. More recently, Koul \& Cuperus (2007) published "Ecologically Based Integrated Pest Management", essentially capturing the breadth and depth of the evolution that IPM has undergone over the past 60 years. While the scope of the "New Solutions" aspect of the NRC's charge has been challenged (Kogan, 1998; Royer et al., 1999), the term "ecologically based" has become infused into the IPM lexicon.

\section{Cultural control methods to reduce insecticide applications}

Cultural controls are management tools and activities that make the crop habitat less favorable for pests to survive and cause damage (Horne \& Page, 2008). Cultural management practices may make the crop or habitat inhospitable to pests directly, for example, by planting cultivars resistant to pest feeding or rotating crops to deny overwintering pests their preferred food source. Cultural management practices can also make the habitat less hospitable to pests in an indirect manner by encouraging natural enemies (predators and parasitoids) to enhance biological control (see Section 3).

Cultural control is a key pest management tool available to growers because the crop variety, habitat, and selected inputs set the stage for future pest fitness and abundance. Thus, implementing preventive cultural control tactics that slow pest population growth can delay or negate the need for insecticide applications and significant plant damage. In this section we outline the major types of cultural control tactics available to growers and other pest management personnel. Our objective is to demonstrate the breadth of tactics that are used, although we do not have the space to consider them in depth. We draw examples from a diversity of well-studied plant systems from field crops to ornamental landscapes to provide examples of how they affect plant-herbivore-natural enemy interactions to reduce pest abundance and damage. 


\subsection{Cultural control via plant resistance}

Plant resistance to herbivores is a cultural control strategy having the most direct influence on herbivore behavior, fitness, and damage. Plant resistance is achieved through three general mechanisms: antibiosis, antixenosis, and tolerance. Antibiosis is the adverse effect of plant physical or chemical traits on arthropod biology (Painter, 1951). This may include reduced size, survival, fecundity, or longevity and increased development time or mortality. Antixenosis is the effect of plant traits on herbivore behavior that reduces herbivore interactions with the plant (Painter, 1951). These effects can include reduced feeding, preference, residence time, or oviposition on plants having particular traits such as trichomes or defensive compounds. Tolerance is a plant trait that reduces the impact of herbivory on plant growth, allowing tolerant plants to sustain herbivore damage but maintain yields similar to undamaged plants (Painter, 1951).

Physical plant traits such as leaf pubescence, trichomes, and epicuticular wax, and chemical traits such as alkaloids and terpenoids have antibiotic and antixenotic effects on herbivores (Kennedy \& Barbour, 1992; Painter, 1951). In the well-studied tomato production system, effects of leaf trichomes as a plant resistance trait are well documented (Kennedy, 2003; Simmons \& Gurr, 2005). Trichomes and associated chemicals confer resistance to some tomato varieties against mites, aphids, whiteflies, beetles, and caterpillars (Gentile \& Stoner, 1968; Heinz \& Zalom, 1995; Kennedy, 2003; Kennedy \& Sorenson, 1985; Simmons \& Gurr, 2005). Trichomes are stiff hairs that sometimes contain chemical glands. Glandular trichomes have chemical exudates that confer resistance through antibiosis and kill or reduce longevity of pests feeding on them and entrap pests that forage on the leaves (Simmons \& Gurr, 2005). Trichomes also have antixenotic effects on herbivore pests. Increasing trichome density can reduce oviposition by many species of beetles, caterpillars, true bugs, and mites. Of particular relevance is the effect of trichome density on whitefly and mites pests (Simmons \& Gurr, 2005). The antibiotic and antixenotic effects of leaf pubescence on whitefly behavior and fitness have been studied in depth in a number of systems such as tomato, tobacco, cucurbits, and ornamental plants (Hoddle et al., 1998; Inbar \& Gerling, 2008).

The soybean aphid offers a current example of how identifying pest resistance in crop plants can benefit IPM. Soybean aphid arrived in the U.S. from Asia in 2000 (Ragsdale et al., 2011). Since that time plant resistance conferred through antibiosis and antixenosis mechanisms has played an important role in mediating the economic impact of this pest on soybean yield (Ragsdale et al., 2011). Aphid fitness is negatively affected in resistant lines because it takes twice as long for aphids to probe into the phloem and initiate feeding (Diaz-Montano et al., 2007). Further, feeding bouts are reduced by more than $90 \%$ from less than 7 minutes per bout in resistant lines compared to greater than 60 minutes in susceptible lines (DiazMontano et al., 2007). Likewise, production of nymphs was reduced by $50-90 \%$ in resistant versus susceptible varieties, confirming antibiosis in resistant lines (Diaz-Montano et al., 2006; Hill et al., 2004). Antixenosis was also demonstrated in resistant varieties wherein adult aphids preferred to colonize susceptible over some resistant lines (Diaz-Montano et al., 2006; Hill et al., 2004).

In contrast to conventional breeding programs, plants can now be genetically modified to include lethal traits from other organisms, such as the bacterium, Bacillus thuringiensis (Bt). Bt genes are now used in many crop species to confer antibiosis in otherwise susceptible crops. Although we do not focus on this mode of plant resistance here, transgenic traits have had a tremendous effect on modern crop production and yield. However, like any 
management tactic, Bt crops do not function in a vacuum and effects on natural enemies and other non-targets, secondary pest outbreaks, and evolution of pest resistance have been intensely studied (Gould, 1998; O'Callaghan et al., 2005; Shelton et al., 2002).

\subsubsection{Interaction of plant resistance traits and biological control}

Effects of plant resistance and biological control can be contradictory, complementary, or synergistic (Cai et al., 2009; Farid et al., 1998; Johnson \& Gould, 1992). Plant resistance can work in conjunction with natural enemies to maintain low pest abundance and damage. In general, natural enemies have slower population growth rates than pests. Thus, by reducing pest population growth rates, plant resistance may help natural enemies better regulate pest populations. For example, research in wheat systems has shown that aphid-resistant wheat varieties do not have negative effects on parasitoid life history parameters such as size and development time (Farid et al., 1998). Parasitism rates may be equal or greater on resistant varieties, which when combined with reduced aphid population growth due to host plant resistance, can improve pest management dramatically (Cai et al., 2009).

Just as trichome exudates reduce herbivore survival they can also have negative effects on natural enemies. Survival and development of natural enemies may be reduced by poisoning or entrapping them, and natural enemy foraging efficiency, predation, or parasitism rate may be inhibited (Kaufman \& Kennedy, 1989a, b; Obrycki \& Tauber, 1984; Simmons \& Gurr, 2005). For example, increasing trichome density and related changes in chemical composition of tomato leaves reduced the walking speed, parasitism rate, and survival of the egg parasitoid, Trichogramma pretiosum (Kashyap et al., 1991a, b). Tiny whitefly parasitoids in the genera, Eretmocerus and Encarsia, are highly affected by plant pubescence and trichome density (Hoddle et al., 1998; van Lenteren et al., 1995). Biological control may be disrupted because these parasitoids avoid highly pubescent plants. Once on the plants, pubescence reduces walking speed, foraging efficiency, oviposition, and parasitism rate (De Barro et al., 2000; Headrick et al., 1996; Hoddle et al., 1998; Inbar \& Gerling, 2008).

Trichomes and other plant resistance traits also affect predator behavior and efficacy. Predatory mites used in biological control of spider mite, Tetranychus urticae, are readily trapped by trichomes and forage less efficiently due to reduced mobility (Nihoul, 1993a; van Haren et al., 1987). The consequence of mortality and reduced foraging efficiency is reduced biological control on cultivars with high trichome density, although the effect is also dependent on environmental factors such as temperature (Nihoul 1993a, b). Likewise, foraging efficiency of the spotted lady beetle, Coleomegilla maculata, and the bigeyed bug, Geocoris punctipes, was reduced by high trichome density, resulting in less predation of Heliothis zea eggs (Barbour et al., 1993, 1997). Increasing pubescence on poinsettia leaves by just 15\% reduced oviposition and whitefly predation by Delphastus catalinae and other predators (Heinz \& Parrella, 1994).

\subsubsection{Herbivore resistance to plant resistance traits}

Herbivores are in a constant evolutionary arms race with plants to overcome resistance traits (Ehrlich \& Raven, 1964). It is not surprising then that pests have developed physiological resistance to genetically modified and conventional plant resistance traits (Gould, 1998). For example, certain soybean aphid biotypes are resistant to Rag1 or Rag2 genes that confer resistance to soybean plants (Hill et al., 2009, 2010). Evidence from 
theoretical and empirical research suggests that multiple resistance traits or genes and a combination of different modes of action such as antibiosis and antixenosis should confer more stable resistance to crops. In addition, mixing resistant and susceptible varieties in the same field can reduce evolution of resistance by insect pest populations (Gould, 1986, 1998).

\subsection{Cultural control via fertility management}

Plant fertility and water stress play a major role in plant susceptibility to herbivore feeding, tolerance to herbivore damage, and herbivore population growth. Nitrogen can be a limiting nutrient for herbivorous insects due to the nitrogen-poor quality of their host plants (Mattson, 1980). Therefore, increasing nitrogen concentration within plants by applying fertilizer has a tendency to increase plant quality for herbivores (Mattson, 1980). Increasing foliar nitrogen can reduce pest development time and increase survival and fecundity, leading to more rapid population growth (Mattson, 1980). Research in potato crops has found that increasing nitrogen fertilization increases leaf consumption, reduces development time, and increases abundance of Colorado potato beetles (Boiteau et al., 2008). Likewise, in greenhouse ornamental production, increasing fertilization increases the fecundity, body size, and development rate of citrus mealybug (Hogendorp et al., 2006), and through similar mechanisms increases population growth rates of whiteflies, thrips, aphids, and spider mites (Bentz et al., 1995; Chau et al., 2005; Chau \& Heinz, 2006; Chow et al., 2009).

In ornamental landscapes, fertilizer is often applied to improve the growth of trees and other plants and increase their resistance to abiotic and biotic stress, including herbivore feeding. However, nitrogen fertilization of trees has been shown to reduce plant resistance to many arthropod pests (Herms, 2002; Kytö et al., 1996). This reduced resistance occurs through a combination of fertilizer effects on plant nutrition for herbivores and defense against herbivores (Herms \& Mattson, 1992). Herms \& Mattson (1992) hypothesized that as nitrogen fertilization stimulates rapid plant growth, carbon available for production of defensive compounds is limited. Thus, over-fertilization of trees, shrubs, and other plants provides a dual benefit to many herbivores via increased nitrogen availability and decreased defensive compounds (Raupp et al., 2010).

\subsection{Cultural control via pesticide selection and management}

Pesticide applications are often an essential aspect of plant culture. Managing the type and frequency of applications is a cultural control tactic with well-documented implications. Insecticides can disrupt natural enemy communities and biological control via several mechanisms. Direct toxicity of pyrethroids and organophosphates to natural enemies has been documented frequently (Desneux et al., 2004b; see Galvan et al., 2005). Direct toxicity of insecticides to natural enemies results in smaller natural enemy populations on crop and landscape plants (Frank \& Sadof, in press; Raupp et al., 2001). Insecticides also cause sublethal effects in parasitoids and predators. For example, the pyrethroid, lambdacyhalothrin, disrupts the host location and oviposition behavior of Aphidius ervi, resulting in lower parasitism rates of aphids (Desneux et al., 2004a).

Non-target impacts on natural enemy communities are not limited to contact insecticides. Systemic neonicotinoids such as imidacloprid and thiamethoxam have lethal and sublethal effects on natural enemy development, fitness, and efficacy (Cloyd \& Bethke, 2009; Desneux et al., 2007). These compounds can reduce survival of developing parasitoids and intoxicate 
predators such as lady beetles and lacewing larvae exposed to the chemicals topically or by feeding on exposed prey (Moser \& Obrycki, 2009; Papachristos \& Milonas, 2008; Smith \& Krischik, 1999; Szczepaniec et al., 2011). Parasitoids are also affected negatively via feeding on plant nectar or hosts exposed to the chemicals (Krischik et al., 2007; Rebek \& Sadof, 2003). The consequence of disrupting natural enemy populations can be outbreaks of primary or secondary pests due to the loss of underlying biological control services (Raupp et al., 2010). Considerable work has documented this effect in field crops, orchards, vineyards, and landscape ornamentals (Penman \& Chapman, 1988; Raupp et al., 2010). The effect is particularly prevalent among spider mites and scale insects that are not killed as easily as their natural enemies by insecticide applications. Pyrethroids and other broad-spectrum insecticides have direct and indirect effects on spider mites that can promote mite outbreaks. First, pyrethroids promote spider mite dispersal from treated to untreated areas of reduced competition (Iftner \& Hall, 1983; Penman \& Chapman, 1983). Spider mites have many predators including lady beetles, predatory bugs, lacewing larvae, and predatory mites. Pyrethroids can promote outbreaks of spider mites indirectly by killing the natural enemies that otherwise help suppress spider mite populations (Penman \& Chapman, 1988).

Predatory mites in the family Phytoseiidae feed on spider mite eggs, juveniles, and adults and are effective at reducing spider mite abundance and damage on plants (McMurtry \& Croft, 1997). In addition, phytoseiid mites often respond with a numerical increase to burgeoning spider mite populations via aggregation and increased reproduction. However, the abundance and efficacy of phytoseiid mites depends in large part on plant culture practices and plant characteristics. Phytoseiid mites are extremely susceptible to insecticides such as pyrethroids, organophosphates, and carbamates (Hardman et al., 1988). In many cases, phytoseiids have been found to be more vulnerable to these insecticides than spider mites (e.g., Sanford, 1967; Wong and Chapman, 1979). Therefore, by killing a disproportionate number of predatory mites compared to target pests, broad-spectrum insecticides frequently lead to spider mite outbreaks (Hardman et al., 1988). Similar dynamics have been demonstrated for scale insects, which are generally not killed by cover sprays of contact insecticides due to their protective cover. Moreover, by drastically reducing natural enemy abundance and efficacy, these insecticide applications create enemy-free space for scales, which can result in outbreak populations (McClure, 1977; Raupp et al., 2001).

Insecticide applications can directly benefit pest reproduction and survival through a process known as hormoligosis. Increased spider mite fecundity has been demonstrated after exposure to sublethal doses of pyrethroids (Iftner \& Hall, 1984; Jones \& Parrella, 1984). However, this is most evident in spider mites that frequently outbreak after applications of the neonicotinoid, imidacloprid (Gupta \& Krischik, 2007; Raupp et al., 2004; Sclar et al., 1998; Szczepaniec et al., 2011). Outbreaks are triggered in part by negative effects on predators, but also by greater fecundity of spider mites that feed on imidacloprid-treated foliage (Szczepaniec et al., 2011). Although not commonly observed, this phenomenon points out another reason for proper insecticide management as a cultural control strategy.

\subsection{Cultural control via crop rotation and planting practices}

Exploiting the biological limitations of the pest to minimize insecticide applications is the essence of cultural control tactics such as crop rotation. This strategy has been used successfully to control corn rootworm for over 100 years (Forbes, 1883). Crop rotation has been highly effective as a tool to reduce Western corn rootworm, Diabrotica virgifera virgifera, 
and Northern corn rootworm Diabrotica barberi, damage in corn (Levine \& Oloumi-Sadeghi, 1991; Spencer et al., 2009). Corn rootworm eggs overwinter in corn fields and larvae are present to feed on corn roots the following year (Spencer et al., 2009). Therefore, rotating to a different crop such as soybeans denies food to hatching rootworm larvae (Spencer et al., 2009). Likewise, corn planted after soybeans or other crops has less rootworm damage because the field is free of overwintering eggs and larvae. However, Western and Northern corn rootworm populations eventually developed resistance to this strategy (Gray et al., 2009; Levine et al., 2002; Spencer \& Levine, 2008). Northern corn rootworms circumvent crop rotation by prolonging egg diapause for two winters instead of one (Chiang, 1965; Levine et al., 1992). Therefore, larvae hatch when fields are replanted in corn two years after the eggs were laid. Western corn rootworm has become resistant to crop rotation by a behavioral rather than physiological mechanism. Western corn rootworm adults move from corn fields to soybean and other crop fields, feeding on soybean leaves and ovipositing in soybean fields (Levine et al., 2002). Selection pressure imposed by rotation of two primary crops, corn and soybeans, strongly rewarded female beetles that strayed from corn for oviposition.

Other planting practices such as delayed planting dates can also benefit pest control. Hessian fly is an introduced pest of winter wheat that has been in the U.S. since the 1700's. Prior to the development of resistant wheat varieties, growers exploited the fly's life cycle to reduce damage to winter wheat crops. Hessian fly adults become active in the fall when they oviposit in wheat and other grasses. By planting after a "fly free date" when fly activity subsides, winter wheat is protected from oviposition from the fall hessian fly generation (Buntin et al., 1991). This is a perfect example of how simple changes in plant culture can reduce the need for insecticide applications, increase yield, and provide economic benefit to growers (Buntin et al., 1992).

\section{Biological control of insect pests}

Many definitions of biological control have been published in the literature since the term was first used by H.S. Smith more than 90 years ago (Caltagirone \& Huffaker, 1980; Cook, 1987; Coppel \& Mertins, 1977; DeBach \& Rosen, 1991; Garcia et al., 1988; see Huffaker \& Messenger, 1976; Perkins \& Garcia, 1999; Rabb, 1972; Smith, 1919). In its strictest sense, biological control is the use of beneficial organisms to reduce the relative abundance of, and damage caused by, noxious ones. This definition attributes economic rather than biological characters to organisms that fall into two categories, beneficial and noxious, based on their positive or negative impact on human-valued resources. It is also important to distinguish biological from natural control, which does not require human intervention, and from similar methods of pest control that do not involve whole (living) organisms (Huffaker et al., 1984). In fact, biological control involves interspecific, population-level processes by way of predation, parasitism, competition, or a combination of these mechanisms (van Driesche \& Bellows, 1996). In practice, the effectiveness and appropriateness of biological control methods rely on real-time evolutionary forces that shape the beneficial organism's genotype, phenotype, and performance. This is not the case for similar, biologically based methods such as the application of insecticides formulated with pathogens, antagonists, or their byproducts. Furthermore, in its strictest definition, biological control does not include the deployment of pest-tolerant organisms, regardless of the source or origin of the resistanceconferring characters (e.g., Bt crops) (see Perkins \& Garcia, 1999). 
The history and origins of biological control have been extensively covered in previous volumes (Caltagirone \& Doutt, 1989; DeBach \& Rosen, 1991; van Driesche \& Bellows, 1996) and is not the subject of this review. However, it is significant to note that early theory and application of biological control principles pre-date the modern insecticide era (Smith, 1919). Therefore, it is modern insecticides that became an alternative to biological control and not the other way around. In this context, biological control should not be viewed as a novel tactic but as the foundation of a successful pest management strategy involving, at minimum, the conservation of ecosystem resources to facilitate the process of pest-natural enemy colonization, host/prey finding, and ultimately, damage reduction. Although what constitutes biological control (or not) continues to be a subject of discussion and will likely evolve with new technologies, the recognition of three principal biological control methods remains unchanged. These three approaches are importation (a.k.a., classical biological control), augmentation, and conservation biological control (Smith, 1919).

\subsection{Importation biological control}

Importation biological control is the oldest of the three approaches (hence its alternative name, 'classical'). The first successful case of importation biological control occurred over a century ago in the control of cottony cushion scale in California citrus following importation of the vedalia beetle (Horn, 1988). The classical approach involves re-establishing the interspecific interactions (and their impact on population regulation) between pests and their natural enemies (i.e., predators, parasitoids, or insect-killing pathogens) as they occur in the pest's endemic range (Howarth, 1983). The need to re-establish these interactions arises because pests are commonly introduced into areas outside their native range where they lack natural enemies, or those that are present do not significantly impact the pest's abundance and local distribution. Since its inception, importation biological control has been used with varying degrees of success against noxious pests like cassava mealybug in Africa, Rhodesgrass mealybug in Texas, walnut aphid in California, and southern green stink bug in Australia, New Zealand, and Hawaii (Hokkanen, 1997).

The technical expertise, time commitment, and considerable expense necessary to carry out importation biological control require the involvement of specially trained university and government scientists. Importation is highly regulated in many countries, largely due to growing concern over the introduction of exotic, invasive species into new environments. In the U.S., the Animal and Plant Health Inspection Service (APHIS) oversees and coordinates importation biological control programs. The agency's charge is to preserve the safety and effectiveness of biological control primarily through post-release monitoring of biological control agents (USDA APHIS, 2011). Although there are a few documented cases of introduced biological control agents causing economic or ecological harm, societal perceptions that importation biological control is too risky are often influenced by subjectivity and misinformation (Delfosse, 2005). To minimize risk, researchers must provide evidence that introduced natural enemies are unlikely to harm crops, humans, and ecosystems. This requires substantial analysis of host feeding preference and other biological traits of prospective biological control agents (see Briese, 2005).

\subsection{Augmentation biological control}

The aim of augmentation biological control is to improve the numerical ratio between pest and natural enemy to increase pest mortality. It involves the release of natural enemies, 
typically mass reared in an insectary, either to inoculate or inundate the target area of impact (Obrycki et al., 1997; Parrella et al., 1992; Ridgway, 1998). Inoculative releases involve relatively low numbers of natural enemies, typically when pest populations are low or at the beginning of a growth cycle or season. Inundation involves relatively high numbers of natural enemies released repeatedly throughout the growth cycle or season. Thus, inundative release of natural enemies is similar to insecticide use in that releases are made when pests achieve high enough density to cause economic harm to the crop. In both types of release, the objective is to inflict high mortality by synchronizing the life cycles of the pest and natural enemy. Hence, an effective monitoring program of pest populations is essential to the success of augmentation biological control.

Augmentation biological control has been used successfully against key pests of field and greenhouse crops. A well-known example of augmentation biological control is the use of the parasitoid, Encarsia formosa, for control of greenhouse whitefly (Hoddle et al., 1998). Indeed, augmentation plays an important role in greenhouse production, especially in Europe, and many natural enemies are commercially available for control of perennial greenhouse pests such as spider mites, aphids, scales, and whiteflies (Grant, 1997; Pottorff \& Panter, 2009). The success of augmentative releases in greenhouses, and elsewhere, depends on the compatibility of cultural practices such as insecticide use with natural enemies (see Section 2.3). Greenhouses are often ideal sites for augmentation biological control because of the relative stability of the enclosed environment. In contrast, a critical review of augmentation biological control in field crops revealed that augmentation was typically less effective and more expensive than conventional control with pesticides (Collier \& van Steenwyk, 2004). The authors found that the low success rate of augmentation biological control in field crops is influenced by ecological limitations such as unfavorable environmental conditions, natural enemy dispersal, and refuge for herbivores from released natural enemies.

\subsection{Conservation biological control}

Conservation biological control involves any practice that increases colonization, establishment, reproduction, and survival of native or previously established natural enemies (Landis et al., 2000). Conservation biological control can be achieved in two ways: modifying pesticide use and manipulating the growing environment in favor of natural enemies. Conservation practices have proven effective in a wide variety of growing situations ranging from small garden plots to large fields, agricultural to urban environments, and commercial to private settings (Frank \& Shrewsbury, 2004; Landis et al., 2000; Rebek et al., 2005, 2006; Sadof et al., 2004; Tooker \& Hanks, 2000).

\subsubsection{Conserving natural enemies via modified pesticide use}

Modifications to pesticide regimens include reducing or eliminating insecticide use, using pest-specific insecticides when needed, making applications when beneficial arthropods are not active, and making treatment decisions based on monitoring and the presence of vulnerable life stages. While total independence from chemical control is not feasible for most situations, reductions in insecticide use are possible through IPM programs based on rigorous pest monitoring, established treatment thresholds, and/or insect population models (see Horn, 1988; Pimental, 1997). Thus, insecticides are used only when needed to prevent crop damage that results in economic loss. When insecticide use is warranted, 
adverse effects on natural enemies can be minimized by using selective, pest-specific products that are only effective against the target pest and its close relatives. Selective chemistries include microbial insecticides, insect growth regulators, botanicals, and novel insecticides with specific modes of action against target insects. Alternatively, insecticide applications can be timed so they not coincide with natural enemy activity; dormant or inactive predators and parasitoids are not exposed to broad-spectrum insecticides applied when they are dormant or inactive (van Driesche \& Bellows, 1996). This strategy requires a thorough understanding of the crop, agroecosystem, and the biology and life cycle of important natural enemies in the system.

\subsubsection{Conserving natural enemies via habitat manipulation}

Natural enemies are attracted to habitats rich in food, shelter, and nesting sites (Landis et al., 2000; Rabb et al., 1976). Many perennial plants can provide these resources when incorporated into the system. Ellis et al. (2005) and Rebek et al. (2005) independently observed significantly enhanced parasitism of two key ornamental pests, bagworm and euonymus scale, in experimental plots containing nectar and pollen sources (i.e., resource plants). Resource plants also served as refuge for vertebrate predators of bagworms as evidenced by increased predation rates (Ellis et al., 2005). Resource plants can harbor alternative prey/host species, which sustain adult and immature natural enemies when primary prey/hosts are scarce. For example, many studies have focused on the influence of banker plants, which contain alternative prey species, on natural enemy effectiveness (see Frank, 2010).

Resource plants provide more than food to enhance natural enemy abundance in impoverished landscapes. Suitable changes in microclimate are afforded by many plants, tempering environmental extremes by providing improved conditions for natural enemy survival (Rabb et al., 1976). Candidate plants include small trees, shrubs, bushy perennials, and tall ornamental grasses with dense canopies or complex architecture. Similarly, organic mulches and ground cover plants can support large numbers of ground-dwelling predators like spiders and ground beetles (Bell et al., 2002; Mathews et al., 2004; Rieux et al., 1999; Snodgrass \& Stadelbacher, 1989), which may enhance biological control of key pests (Brust, 1994). Finally, resource plants can enhance reproduction of natural enemies and provide refuge from their own enemies (Landis et al., 2000; Rabb et al., 1976).

The effectiveness of habitat manipulation to improve biological control requires careful planning and selection of plant attributes that are appropriate for the natural enemy complex present in the system (Landis et al., 2000). For example, flower morphology can significantly impact nectar accessibility by foraging parasitoids (Patt et al., 1997; Wäckers, 2004). Also important is coincidence of floral bloom with natural enemy activity. Selected resource plants should overlap in blooming periods to ensure a continuous supply of nectar and pollen to natural enemies (Bowie et al., 1995; Rebek et al., 2005). Other considerations that exceed the scope of this chapter include the influence of landscape-level attributes on biological control at different spatial scales (Kruess \& Tscharntke, 1994; Marino \& Landis, 1996; Roland \& Taylor, 1997).

\subsection{Factors affecting success of biological control}

While there have been some tremendous successes, the worldwide rate of effective biological control is estimated to be between 16-25\% (Hall et al., 1980; Horn, 1988; van 
Lenteren, 1980). In practice, the successful application of biological control usually requires a combination of at least two of the three approaches, importation, augmentation, and conservation of natural enemies (DeBach \& Rosen, 1991; van Driesche \& Bellows, 1996). What drives the success or failure of biological control programs in plant crops has been the subject of many analyses, either using historical records or theoretical approaches (Andow et al., 1997; Murdoch et al., 1985; Murdoch \& Briggs, 1996; van Lenteren, 1980). In general terms, biological control programs are more likely to succeed under certain production systems and environmental conditions (Clausen, 1978; van Driesche \& Heinz, 2004). Biological control has been more successful in crops that: 1) are perennial versus annual; 2) grow in areas with few pests versus many pests; 3 ) the harvested portion is not damaged by the target pest; 4) the target pest is not a disease vector; and 5) the aesthetic damage is acceptable (e.g., some food and fiber crops versus ornamentals).

Failures in biological control programs, especially those recorded in the literature, also involve cases where the biology and ecology of the natural enemy or the pests are not well understood or altogether unknown. Historically, failures in importation biological control have occurred after errors in identification of a pest or natural enemy at the level of species, biotype, or even local strain; a mismatch in micro-environmental requirements for natural enemy growth and development; incorrectly timing natural enemy release when the production system is not conducive to establishment; or when socioeconomic or regulatory barrier have prevented adoption or implementation (Clausen, 1978; Greathead, 1976; Hall \& Ehler, 1979; Knutson, 1981). Similarly, failures in augmentation and conservation biological control, although not commonly recorded in the literature, may be due to a lack of understanding of the basic biology and ecology of the species involved, the basic requirements of the production system, and any socioeconomic barriers including real or perceived costs and benefits (Murdoch et al., 1985; Perkins \& Garcia, 1999; Collier \& van Steenwyk, 2004). The success of biological control programs involves integrated efforts at many levels ranging from biology to economics, from research to implementation and experience, and from the farm to the community and region.

\section{Physical control strategies to reduce pest incidence}

Plant health can benefit greatly from preventing or limiting injury from arthropod pests from the start. Indeed, the cornerstone of an effective IPM program is prevention, which can be achieved, in part, through physical control. Physical control strategies include methods for excluding pests or limiting their access to crops, disrupting pest behavior, or causing direct mortality (Vincent et al., 2009). Physical control methods can be categorized as active and passive (Vincent et al., 2009). Active methods involve the removal of individual pests by hand, pruning out infested plant tissues, and rogueing out heavily infested plants. Passive methods usually include the use of a device or tool for excluding or removing pests from a crop. Typically, these devices serve as barriers between plants and insect pests, thus protecting plants from injury and damage. Other passive tools include repellents and traps. While traps are often used for monitoring pest abundance and distribution, many are designed as "attract and kill" technologies, which attract insect pests through color, light, shape, texture, and scent, or a combination of these factors.

The greatest disadvantage to physical control is that these methods can be laborious and time consuming, especially for crops grown in large areas. Also, a moderate degree of specialization or training is often required due to the highly technical nature of some 
physical control methods. Physical control methods may also be difficult or practically impossible in some crops like large trees grown in extensive monocultures (e.g., timber production). For many crops, however, physical control of certain pests can be incorporated into established routines for managing crops. Despite the drawbacks and considering the costs, regulations, and limitations of insecticide use, physical control methods are likely candidates for inclusion in many pest management programs, especially for high-value crops (see Vincent et al. 2003). Here, we discuss briefly some examples of physical control classified by their primary function: exclusion, behavior modification, and destruction of pests.

\subsection{Physical control via exclusion}

Pest exclusion is a key factor in preventing pests from accessing crops, thereby reducing the economic impact of insects. Both passive and active exclusion methods have been implemented in various agricultural systems including fields, greenhouses, and postharvest facilities. Physical control via exclusion devices is perhaps most important in protected environments such as greenhouses and grain bins, where optimal temperatures and humidity, a readily available food source, and a general lack of natural enemies contribute to the proliferation of pest populations. Screens are common passive exclusion devices used in greenhouse production. Screens can prevent pest migration into greenhouses through vents and other openings, especially when insect populations build up in weeds and crops in the surrounding environment (Gill et al., 2006; Pottorff \& Panter, 2009). However, screen mesh size is an important concern as fine materials with small openings inhibit entry of tiny arthropods such as thrips and mites but also restrict air flow for cooling (Pottorff \& Panter, 2009). Other active methods of physical control are necessary components of greenhouse IPM. Specifically, crops should be inspected for pests prior to moving new plant materials into production areas; discovered pests are removed by hand, pruned out, or discarded and destroyed with heavily infested plants.

In the field, floating row covers can exclude important vegetable pests such as cabbage maggot, flea beetles, and cabbageworm (Rekika et al., 2008; Theriault et al., 2009). Adhesives and burlap have been used to trap caterpillar pests such as gypsy moth and cankerworms as they migrate vertically along tree trunks (Potter, 1986). Other barriers include fences, ditches, moats, or trenches. For example, V-shaped trenches have been used around potato fields to prevent movement of Colorado potato beetle into the crop from adjacent, overwintering habitat (Boiteau \& Vernon, 2001; Misener et al., 1993; see Vincent et al., 2003). Efficacy of this technique relies on trench design and knowledge of the pest, specifically, the population size and the ratio of crawling to flying individuals (Weber et al., 1994; Vincent et al., 2003).

\subsection{Physical control via behavior modification}

IPM programs often consist of physical control methods that alter the behavior of insect pests. Behaviors such as reproduction, aggregation, oviposition, feeding, alarm, and defense can be modified in two ways: "push-pull" strategies and mating disruption (Cook et al., 2007; Zalom, 1997). The former are designed to repel (push) or attract (pull) insect pests away from a crop by exploiting their reproductive, feeding, or aggregation behavior. Although many repellents and attractants are chemically based, here we treat their use in IPM as a form of non-chemical (non-insecticidal) control.

Pheromones, or chemical lures, are used in IPM programs to monitor pest populations and modify their behavior. Specifically, pheromone traps are used to detect pest activity in a 
crop and estimate their relative abundance in order to properly time an insecticide application or natural enemy release. Pheromones and other olfactory stimuli are receiving increased attention as repellents and attractants in push-pull strategies for modifying pest behavior (see Cook et al., 2007). Repellents include synthetic chemicals (e.g., DEET), nonhost volatiles that mask host plant odors (e.g., essential oils), anti-aggregation and alarm pheromones, anti-feedants (e.g., neem oil), and oviposition deterrents (e.g., ovipositiondeterring pheromones) (Cook et al., 2007). Herbivore-induced plant volatiles are host plant semiochemicals that induce plant defense from herbivores and attract natural enemies (James, 2003). Non-chemical repellents include reflective mulches, which have been shown to reduce damage and population density of tarnished plant bug in strawberry fields (Rhainds et al., 2001). Attractants include sex and aggregation pheromones, host plant volatiles, and feeding stimulants (e.g., baits), and oviposition stimulants (Cook et al., 2007). Other attractants are based on visual cues. For example, apple maggots are effectively controlled in apple orchards with $8-\mathrm{cm}$, red, spherical traps covered in adhesive. The attractiveness of these traps is enhanced by adding butyl hexanoate and ammonium acetate, synthetic olfactory stimulants (Prokopy et al., 1994).

Another common tactic is to use sex pheromones for mating disruption. Many insect pests rely on a species-specific, sex pheromone produced by females for mate location and recognition. Mating disruption is achieved by flooding the crop environment with the chemical signal, thus confusing males and reducing mate-finding success. This approach has been used with varying degrees of success for management of orchard and vineyard pests including codling moth, oriental fruit moth, grape berry moth, and peachtree borer (see Zalom, 1997).

\subsection{Physical control via pest destruction}

Insects can be killed directly through mechanical, thermal, or other means. Vincent et al. (2009) list several strategies that inflict mortality on pests including freezing, heating, flaming, crushing, and irradiating. One of the most common mechanical methods requires no specialized equipment - many gardeners derive great satisfaction from hand picking pests from a plant and crushing them. Hand removal can be used effectively for a myriad of relatively sessile landscape pests including bagworms, tent caterpillars, and sawfly larvae. Galls, egg masses, and web-making insects can also be pruned out of infested landscape plants (Potter, 1986). However, this tactic may be impractical for large trees or shrubs and dense populations of the pest. Other mechanical control options require specialized machinery. Pneumatic control involves removing pests from crops by use of a vacuum or blower and subsequently destroying them. Field crop pests such as Colorado potato beetle and lygus bug have been controlled in this manner, although care must be taken to avoid negatively impacting natural enemies (Vincent et al., 2003, 2009). Another example of mechanized destruction is the entoleter, an impact machine that is used in mills to remove and kill all life stages of insect pests (Vincent et al., 2003).

Modifying the microclimate can be effective in killing many insect pests, which cannot survive outside of optimal temperature and humidity ranges. Heat has been shown to be a very effective control method for bed bugs, which are difficult to control and are becoming more prevalent in domestic dwellings worldwide (Pereira et al., 2009). A wide variety of stored product pests can be controlled by pumping hot or cold air into the food storage facility, or modifying the storage environment with elevated temperatures and carbon 
dioxide (Vincent et al., 2003, 2009). Hot-water immersion, flaming, steaming, and solar heating are other thermal control options (Vincent et al., 2003).

Electromagnetic energy has been studied for its effectiveness at killing insects (Vincent et al., 2009). Ionizing radiation has been used in quarantine facilities to treat fruit and other commodities suspected of carrying serious agricultural pests (Vincent et al., 2003). Targets of other electromagnetic methods, especially microwave treatments, include stored product pests. However, electromagnetic treatments may be limited by government regulations, cost, and the need for specialized equipment and training (Vincent et al., 2009).

\section{Conclusions}

Crop culture sets the stage for interactions between plants, pests, and natural enemies, and has a strong influence on the outcome of these interactions. In many cases, implementing effective cultural controls can be the most economical pest management tactic available to growers because labor and expense are incurred regardless of whether an effective cultural tactic is used. Understanding and implementing cultural practices can reduce other production expenses such as insecticides and fertilizer. Cultural control can be compatible with biological control if the myriad interactions among plants, pests, and natural enemies are well defined. Improving the predictability of biological control will rely on elevating the discipline to its proper place in applied evolutionary ecology and further refinement of the art and practice of biological control (van Lenteren, 1980; Heinz et al., 1993; Heinz, 2005). Fortunately, the organic and sustainable agriculture movements that are gaining both societal and political momentum seem to embrace the art and science of biological pest control (Edwards, 1990; Raynolds, 2000). While various physical control techniques have been used successfully in production systems, this strategy is limited by the significant labor, time, cost, and specialization required for successful control (Vincent et al., 2009). Further refinements and developments in physical control technologies hold promise for enhanced efficacy, compatibility with cultural and biological control, and profits.

As we move into the future of pest management, new challenges await. Crops are now genetically modified to produce their own "insecticides" for protection. Newly registered insecticides tend to be more target specific and often, more expensive. Older chemistries are being removed both voluntarily and involuntarily from the market. There is increasing demand for organically grown food, or food perceived as "safe" for consumption. Yet we must still feed a growing human population. More than ever, IPM researchers need to develop programs that use effective alternatives to insecticides whenever possible. We also must intensify efforts to truly integrate insecticides selectively into our IPM programs, so that they are not the predominant tool in our IPM toolbox. As such, we need to further develop principles and methods of cultural, biological, and physical control as relevant pest management tools for sustainable agricultural production.

\section{References}

Andow, D. A., Ragsdale, D. W., \& Nyvall, R. F. (Eds.) (1997). Ecological Interactions and Biological Control. Intercept Ltd., ISBN 0813387582, Andover, Hants, UK

Barbour, J. D., Farrar, R. R., Jr., \& Kennedy, G. G. (1993). Interaction of Manduca sexta resistance in tomato with insect predators of Helicoverpa zea. Entomologia 
Experimentalis et Applicata, Vol. 68, No. 2, (August 1993), pp. 143-155, ISSN 00138703

Barbour, J. D., Farrar, R. R., Jr., \& Kennedy, G. G. (1997). Populations of predaceous natural enemies developing on insect-resistant and susceptible tomato in North Carolina. Biological Control, Vol. 9, No. 3, (July 1997), pp. 173-184, ISSN 1049-9644

Bell, J. R., Johnson, P. J., Hambler, C., Haughton, A. J., Smith, H., Feber, R. E., Tattersall, F. H., Hart, B. H., Manley, W., \& Macdonald, D. W. (2002). Manipulating the abundance of Lepthyphantes tenuis (Araneae: Linyphiidae) by field margin management. Agriculture, Ecosystems and Environment, Vol. 93, No. 1-3, (December 2002), pp. 295-304, ISSN 0167-8809

Benbrook, C. M., Groth, E., III, Halloran, J. M., Hansen, M. K., \& Marquardt, S. (1996). Pest Management at the Crossroads. Consumers Union of the United States, ISBN 0890439001, New York, New York, USA

Bentz, J. A., Reeves, J., Barbosa, P., \& Francis, B. (1995). Nitrogen fertilizer effect on selection, acceptance, and suitability of Euphorbia pulcherrima (Euphorbiaceae) as a host plant to Bemisia tabaci (Homoptera: Aleyrodidae). Environmental Entomology, Vol. 24, No. 1, (February 1995), pp. 40-45, ISSN 0046-225X

Boiteau, G., Lynch, D. H., \& Martin, R. C. (2008). Influence of fertilization on the Colorado potato beetle, Leptinotarsa decemlineata, in organic potato production. Environmental Entomology, Vol. 37, No. 2, (April 2008), pp. 575-585, ISSN 0046-225X

Boiteau, G., \& Vernon, R. S. (2001). Physical Barriers for the Control of Insect Pests, In: Physical Control Methods in Plant Protection, C. Vincent, B. Panneton, \& F. FleuratLessard (Eds.), pp. 224-247, Springer, ISBN 3540645624, Berlin, Germany

Bowie, M. H., Wratten, S. D., \& White, A. J. (1995). Agronomy and phenology of "companion plants" of potential for enhancement of insect biological control. New Zealand Journal of Crop and Horticultural Science, Vol. 23, No. 4, (December 1995), pp. 423-427, ISSN 0114-0671

Briese, D. T. (2005). Translating host-specificity test results into the real world: the need to harmonize the yin and yang of current testing procedures. Biological Control, Vol. 35, No. 3, (December 2005), pp. 208-214, ISSN 1049-9644

Brust, G. E. (1994). Natural enemies in straw-mulch reduce Colorado potato beetle populations and damage in potato. Biological Control, Vol. 4, No. 2, (June 1994), pp. 163-169, ISSN 1049-9644

Buntin, G. D., \& Hudson, R. D. (1991). Spring control of the hessian fly (Diptera: Cecidomyiidae) in winter wheat using insecticides. Journal of Economic Entomology, Vol. 84, No. 6, (December 1991), pp. 1913-1919, ISSN 0022-0493

Buntin, G. D., Ott, S. L., \& Johnson, J. W. (1992). Integration of plant resistance, insecticides, and planting date for management of the hessian fly (Diptera: Cecidomyiidae) in winter wheat. Journal of Economic Entomology, Vol. 85, No. 2, (April 1992), pp. 530538, ISSN 0022-0493

Cai, Q. N., Ma, X. M., Zhao, X., Cao, Y. Z., \& Yang, X. Q. (2009). Effects of host plant resistance on insect pests and its parasitoid: a case study of wheat-aphid-parasitoid system. Biological Control, Vol. 49, No. 2, (May 2009), pp. 134-138, ISSN 1049-9644

Caltagirone, L. E. \& Huffaker, C. B. (1980). Benefits and Risks of Using Natural Enemies for Controlling Pests, In: Environmental Protection and Biological Forms of Control of Pest 
Organisms, Ecological Bulletins No. 31, B. Lundsholm \& M. Stackerud (Eds.), pp. 103-109, Swedish Natural Science Research Council, Stockholm, Sweden.

Caltagirone, L. E., \& Doutt, R. L. (1989). The history of the vedalia beetle importation to California and its impact on the development of biological control. Annual Review of Entomology, Vol. 34, pp. 1-16, ISSN 0066-4170

Carson, R. (1962). Silent Spring. Houghton Mifflin Co., New York, New York, USA

Chau, A., \& Heinz, K. M. (2006). Manipulating fertilization: a management tactic against Frankliniella occidentalis on potted chrysanthemum. Entomologia Experimentalis et Applicata, Vol. 120, No. 3, (September 2006), pp. 201-209, ISSN 0013-8703

Chau, A., Heinz, K. M., \& Davies, F. T. (2005). Influences of fertilization on Aphis gossypii and insecticide usage. Journal of Applied Entomology, Vol. 129, No. 2, (March 2005), pp. 89-97, ISSN 0931-2048

Chiang, H. C. (1965). Survival of northern corn rootworm eggs through one and two winters. Journal of Economic Entomology, Vol. 58, No. 3, (April 1965), pp. 470-472, ISSN 0022-0493

Chow, A., Chau, A., \& Heinz, K. M. (2009). Reducing fertilization for cut roses: effect on crop productivity and twospotted spider mite abundance, distribution, and management. Journal of Economic Entomology, Vol. 102, No. 5, (October 2009), pp. 1896-1907, ISSN 0022-0493

Clausen, C. P., (Ed.) (1978). Introduced Parasites and Predators of Arthropod Pests and Weeds: a World Review, Agriculture Handbook No. 480, Agricultural Research Service, United States Department of Agriculture, Washington, D.C., USA

Cloyd, R. A., \& Bethke, J. A. 2009. Pesticide use in ornamental production: what are the benefits? Pest Management Science, Vol. 65, No. 4, (April 2009), pp. 345-350, ISSN 1526-498X

Collier, T., \& van Steenwyk, R. (2004). A critical evaluation of augmentative biological control. Biological Control, Vol. 31, No. 2, (October 2004), pp. 245-256, ISSN 10499644

Cook, R. J. (1987). Report of the Research Briefing Panel on Biological Control in Managed Ecosystems. National Academy Press, Washington, D.C., USA

Cook, S. M., Kahn, Z. R., \& Pickett, J. A. (2007). The use of push-pull strategies in integrated pest management. Annual Review of Entomology, Vol. 52, pp. 375-400. ISSN 00664170

Coppel, H. C., \& Mertins, J. W. (1977). Biological Insect Pest Suppression, Advanced Series in Agricultural Sciences, Vol. 4, Springer-Verlag., Berlin, Germany

DeBach, P. D., \& Rosen, D. (1991). Biological Control by Natural Enemies (2nd edition), Cambridge University Press, ISBN 0521391911, London, UK

De Barro, P. J., Hart, P. J., \& Morton, R. (2000). The biology of two Eretmocerus spp. (Haldeman) and three Encarsia spp. Forster and their potential as biological control agents of Bemisia tabaci biotype B in Australia. Entomologia Experimentalis et Applicata, Vol. 94, No. 1, (January 2000), pp. 93-102, ISSN 0013-8703

Delfosse, E. S. (2005). Risk and ethics in biological control. Biological Control, Vol. 35, No. 3, (December 2005), pp. 319-329, ISSN 1049-9644

Desneux, N., Decourtye, A., \& Delpuech, J. M. (2007). The sublethal effects of pesticides on beneficial arthropods. Annual Review of Entomology, Vol. 52, pp. 81-106, ISSN 00664170 
Desneux, N., Pham-Delègue, M. H., \& Kaiser, L. (2004a). Effect of a sublethal and lethal dose of lambdacyhalothrin on oviposition experience and host searching behaviour of a parasitic wasp, Aphidius ervi. Pest Management Science, Vol. 60, No. 4, (April 2004), pp. 381-389, ISSN 1526-498X

Desneux N., Rafalimanana, H., Kaiser, L. (2004b). Dose-response relationship in lethal and behavioural effects of different insecticides on the parasitic wasp Aphidius ervi. Chemosphere, Vol. 54, No. 5, (February 2004), pp. 619-627, ISSN 0045-6535

Diaz-Montano, J., Reese, J. C., Louis, J., Campbell, L. R., \& Schapaugh, W. T. (2007). Feeding behavior by the soybean aphid (Hemiptera: Aphididae) on resistant and susceptible soybean genotypes. Journal of Economic Entomology, Vol. 100, No. 3, (June 2007), pp. 984-989, ISSN 0022-0493

Diaz-Montano, J., Reese, J. C., Schapaugh, W. T., \& Campbell, L. R. (2006). Characterization of antibiosis and antixenosis to the soybean aphid (Hemiptera: Aphididae) in several soybean genotypes. Journal of Economic Entomology, Vol. 99, No. 5, (October 2006), pp. 1884-1889, ISSN 0022-0493

Edwards, C. A., Lal, R., Madden, P., Miller, R. H., \& House, G. (Eds.) (1990). Sustainable Agricultural Systems, Soil and Water Conservation Society, ISBN 093573421X, Ankeny, Iowa, USA

Ehrlich, P. R., \& Raven, P. H. (1964). Butterflies and plants: a study in coevolution. Evolution, Vol. 18, No. 4, (December 1964), pp. 586-608, ISSN 0014-3820

Ellis, J. A., Walter, A. D., Tooker, J. F., Ginzel, M. D., Reagel, P. F., Lacy, E. S., Bennett, A. B., Grossman, E. M., \& Hanks, L. M. (2005). Conservation biological control in urban landscapes: manipulating parasitoids of bagworm (Lepidoptera: Psychidae) with flowering forbs. Biological Control, Vol. 34, No. 1, (July 2005), pp. 99-107, ISSN 10499644

Farid A., Johnson, J. B., Shafii, B., \& Quisenberry, S. S. (1998). Tritrophic studies of Russian wheat aphid, a parasitoid, and resistant and susceptible wheat over three parasitoid generations. Biological Control, Vol. 12, No. 1, (May 1998), pp. 1-6, ISSN 1049-9644

Forbes, S. A. (1883). The corn root-worm. (Diabrotica longicornis Say) Order Coleoptera. Family Chrysomelidae. Illinois State Entomologist Annual Report, Vol. 12, pp. 10-31

Frank, S. D. (2010). Biological control of arthropod pests using banker plant systems: past progress and future direction. Biological Control, Vol. 52, No. 1, (January 2010), pp. 8-16, ISSN 1049-9644

Frank, S. D., \& Sadof, C. S. In press. Reducing insecticide volume and non-target effects of ambrosia beetle management in nurseries. Submitted to Journal of Economic Entomology.

Frank, S. D., \& Shrewsbury, P. M. (2004). Effect of conservation strips on the abundance and distribution of natural enemies and predation of Agrotis ipsilon (Lepidoptera: Noctuidae) on golf course fairways. Environmental Entomology, Vol. 33, No. 6, (December 2004), pp. 1662-1672, ISSN 0046-225X

Frisbie, R. E., \& Smith, J. W., Jr. (1989). Biologically Intensive Integrated Pest Management: the Future. In: Progress and Perspectives for the 21st Century, J. J. Menn \& A. L. Stienhauer (Eds.), pp. 156-184, Entomological Society of America, ISBN 0938522361, Lanham, Maryland, USA 
Galvan, T. L., Koch, R. L., \& Hutchison, W. D. (2005). Toxicity of commonly used insecticides in sweet corn and soybean to multicolored Asian lady beetle (Coleoptera: Coccinellidae). Journal of Economic Entomology, Vol. 98, No. 3, (June 2005), pp. 780-789, ISSN 0022-0493

Garcia, R., Caltagirone, L. E., \& Gutierrez, A. P. (1988). Comments on a redefinition of biological control. BioScience, Vol. 38, No. 10, (November 1988), pp. 692-694, ISSN 0006-3568

Gentile, A. G., \& Stoner, A. K. (1968). Resistance in Lycopersicon and Solanum species to potato aphid. Journal of Economic Entomology, Vol. 61, No. 5, (October 1968), pp. 1152-54, ISSN 0022-0493

Gill, S., Cloyd, R. A., Baker, J. R., Clement, D. L., \& Dutky, E., (2006). Pests and Diseases of Herbaceous Perennials: the Biological Approach. Ball Publishing, ISBN 1883052508, Batavia, IL, USA

Gould, F. (1986). Simulation models for predicting durability of insect-resistant germ plasm - hessian fly (Diptera: Cecidomyiidae)-resistant winter wheat. Environmental Entomology, Vol. 15, No. 1, (February 1986), pp. 11-23, ISSN 0046-225X

Gould, F. (1998). Sustainability of transgenic insecticidal cultivars: integrating pest genetics and ecology. Annual Review of Entomology, Vol. 43, pp. 701-726, ISSN 0066-4170

Grant, J. A. (1997). IPM techniques for greenhouse crops. In: Techniques for Reducing Pesticide Use: Economic and Environmental Benefits, D. Pimental (Ed.), pp. 399-406, John Wiley and Sons, ISBN 0471968382, Chichester, West Sussex, UK

Gray, M. E., Sappington, T. W., Miller, N. J., Moeser, J., \& Bohn, M. O. (2009). Adaptation and invasiveness of western corn rootworm: intensifying research on a worsening pest. Annual Review of Entomology, Vol. 54, pp. 303-321, ISSN 0066-4170

Greathead, D. J., (Ed.) (1976). A Review of Biological Control in Western and Southern Europe, Technical Communication Vol. 7, pp. 52-64, Commonweath Institute for Biological Control, Commonwealth Agricultural Bureau, ISBN 0851983693, Slough, UK

Gupta, G., \& Krischik, V. A. (2007). Professional and consumer insecticides for the management of adult Japanese beetle on hybrid tea rose. Journal of Economic Entomology, Vol. 100, No. 3, (June 2007), pp. 830-837, ISSN 0022-0493

Hall, R. W., \& Ehler, L. E. (1979). Rate of establishment of natural enemies in classical biological control. Bulletin of the Entomological Society of America, Vol. 25, No. 4, (15 December 1979), pp. 280-282, ISSN 0013-8754

Hall, R. W., Ehler, L. E., \& Bisabri-Ershadi, B. (1980). Rate of success in classical biological control of arthropods. Bulletin of the Entomological Society of America, Vol. 26, No. 2, (15 June 1980), pp. 111-114, ISSN 0013-8754

Hardman, J. M., Rogers, R. E. L., \& MacLellan, C. R. (1988). Advantages and disadvantages of using pyrethroids in Nova Scotia apple orchards. Journal of Economic Entomology, Vol. 81, No. 6, (December 1988), pp. 1737-1749, ISSN 0022-0493

Headrick, D. H., Bellows, T. S., Jr., \& Perring, T. M. (1996). Behaviors of female Eretmocerus sp. nr. californicus (Hymenoptera: Aphelinidae) attacking Bemisia argentifolii (Homoptera: Aleyrodidae) on cotton, Gossypium hirsutum (Malavaceae), and melon, Cucumis melo (Cucurbitaceae). Biological Control, Vol. 6, No. 1, (February 1996), pp. 64-75, ISSN 1049-9644

Heinz, K. M., Nunney, L., \& Parrella, M. P. (1993). Towards predictable biological control of Liriomyza trifolii (Diptera: Agromyzidae) infesting greenhouse cut 
Chrysanthemums. Environmental Entomology, Vol. 22, No. 6, (December 1993), pp. 1217-1233, ISSN 0046-225X

Heinz, K. M., \& Parrella, M. P. (1994). Poinsettia (Euphorbia pulcherrima Willd. ex Koltz.) cultivar-mediated differences in performance of five natural enemies of Bemisia argentifolii Bellows and Perring, n. sp. (Homoptera: Aleyrodidae). Biological Control, Vol. 4, No. 4, (December 1994), pp. 305-318, ISSN 1049-9644

Heinz, K. M., \& Zalom, F. G. (1995). Variation in trichome-based resistance to Bemisia argentifolii (Homoptera: Aleyrodidae) oviposition on tomato. Journal of Economic Entomology, Vol. 88, No. 5, (October 1995), pp. 1494-1502, ISSN 0022-0493

Heinz, K. M. (2005). Evolutionary Pest Management: an Approach to the Twenty-First Century, In: Entomology at the Land Grant University: Perspectives from the Texas AEM University Department Centenary, K. M. Heinz, R. E. Frisbie, \& C. E. Bográn (Eds.), pp. 305-315, Texas A\&M University Press, ISBN 1585444324 College Station, Texas, USA

Herms, D. A. (2002). Effects of fertilization on insect resistance of woody ornamental plants: reassessing an entrenched paradigm. Environmental Entomology, Vol. 31, No. 6, (December 2002), pp. 923-933, ISSN 0046-225X

Herms, D. A., \& Mattson, W. J. (1992). The dilemma of plants - to grow or defend. Quarterly Review of Biology, Vol. 67, No. 3, (September 1992), pp. 283-335, ISSN 0033-5770

Hill, C. B., Crull, L., Herman, T., Voegtlin, D. J., \& Hartman, G. L. (2010). A new soybean aphid (Hemiptera: Aphididae) biotype identified. Journal of Economic Entomology, Vol. 103, No. 2, (April 2010), pp. 509-515, ISSN 0022-0493

Hill, C. B., Kim, K. S., Crull, L., Diers, B. W., \& Hartman G. L. (2009). Inheritance of resistance to the soybean aphid in soybean PI 200538. Crop Science, Vol. 49, No. 4, (July/August 2009), pp. 1193-1200, ISSN 0011-183X

Hill, C. B., Li, Y., \& Hartman, G. L. (2004). Resistance of Glycine species and various cultivated legumes to the soybean aphid (Homoptera: Aphididae). Journal of Economic Entomology, Vol. 97, No. 3, (June 2004), pp. 1071-1077, ISSN 0022-0493

Hoddle, M. S., van Driesche, R. G., \& Sanderson, J. P. (1998). Biology and use of the whitefly parasitoid Encarsia formosa. Annual Review of Entomology, Vol. 43, pp. 645-669, ISSN 0066-4170

Hogendorp, B. K., Cloyd, R. A., \& Swiader, J. M. (2006). Effect of nitrogen fertility on reproduction and development of citrus mealybug, Planococcus citri Risso (Homoptera: Pseudococcidae), feeding on two colors of coleus, Solenostemon scutellarioides L. Codd. Environmental Entomology, Vol. 35, No. 2, (April 2006), pp. 201-211, ISSN 0046-225X

Hokkanen, H. M. T. (1997). Role of Biological Control and Transgenic Crops in Reducing Use of Chemical Pesticides for Crop Protection, In: Techniques for Reducing Pesticide Use: Economic and Environmental Benefits, D. Pimental (Ed.), pp. 103-127, John Wiley and Sons, ISBN 0471968382, Chichester, West Sussex, UK

Horn, D. J. (1988). Ecological Approach to Pest Management. The Guilford Press, ISBN 0898623022, New York, New York, USA

Horne, P., \& Page, J. (2008). Integrated Pest Management for Crops and Pastures. Landlinks Press, ISBN 0643092579, Collingwood, Australia 
Hoskins, W.M., Borden, A. D., \& Michelbacher, A.E. (1939). Recommendations for a more discriminating use of insecticides, In: Proceedings of the $6^{\text {th }}$ Pacific Science Congress, Vol. 5, pp. 119-123

Howarth, F. G. (1983). Classical biological control: panacea or Pandora's box? Proceedings of the Hawaiian Entomological Society, Vol. 24, pp. 239-244, ISSN 0073-134X

Huffaker, C. B., Berryman, A. A., \& Laing, J. E. (1984). Natural Control of Insect Populations, In: Ecological Entomology, C. B. Huffaker \& R.L. Rabb (Eds.), pp. 359398, Wiley, ISBN 0471064939, New York, New York, USA

Huffaker, C. B., \& Messenger, P. S. (Eds.) (1976). Theory and Practice of Biological Control. Academic Press, ISBN 0123603501, New York, New York, USA

Iftner, D. C., \& Hall, F. R. (1983). Effects of fenvalerate and permethrin on Tetranychus urticae Koch (Acari: Tetranychidae) dispersal behavior. Environmental Entomology, Vol. 12, No. 6, (December 1983), pp. 1782-1786, ISSN 0046-225X

Iftner, D. C., \& Hall, F. R. (1984). The effects of fenvalerate and permethrin residues on Tetranychus urticae Koch fecundity and rate of development. Journal of Agricultural Entomology, Vol. 1, pp. 191-200, ISSN 0735-939X

Inbar, M., \& Gerling, D. (2008). Plant-mediated interactions between whiteflies, herbivores, and natural enemies. Annual Review of Entomology, Vol. 53, pp. 431-448, ISSN 00664170

Insecticide Resistance Action Committee (IRAC) (2010). 03.08.11, Available from http://www.irac-online.org/about/irac/

Jacobsen, B. J. (1997). Role of plant pathology in integrated pest management. Annual Review of Phytopathology, Vol. 35, pp. 373-391, ISSN 0066-4286

James, D. G. (2003). Synthetic herbivore-induced plant volatiles as field attractants for beneficial insects. Environmental Entomology, Vol. 32, No. 5, (October 2003), pp. 977982, ISSN 0046-225X

Johnson, M. T., \& Gould, F. (1992). Interaction of genetically engineered host plantresistance and natural enemies of Heliothis virescens (Lepidoptera: Noctuidae) in tobacco. Environmental Entomology, Vol. 21, No. 3, (June 1992), pp. 587-597, ISSN 0046-225X

Jones, V. P., \& Parella, M. P. (1984). The sublethal effects of selected insecticides on life table parameters of Panonychus citri (Acari: Tetranychidae). Canadian Entomologist, Vol. 116, pp. 1033-1040, ISSN 0008-347X

Kashyap, R. K., Kennedy, G. G., \& Farrar, R. R., Jr. (1991a). Behavioral response of Trichogramma pretiosum Riley and Telenomus sphingis (Ashmead) to trichmone/ methyl ketone-mediated resistance in tomato. Journal of Chemical Ecology, Vol. 17, No. 3, (March 1991), pp. 543-556, ISSN 0098-0331

Kashyap, R. K., Kennedy, G. G., \& Farrar, R. R., Jr. (1991b). Mortality and inhibition of Helicoverpa zea egg parasitism rates by Trichogramma in relation to trichome/ methyl ketone-mediated insect resistance of Lycopersicon hirsutum f. glabratum accession PI134417. Journal of Chemical Ecology, Vol. 17, No. 12, (December 1991), pp. 2381-2395, ISSN 0098-0331

Kaufman, W. C., \& Kennedy, G. G. (1989a). Inhibition of Campoletis sonorensis parasitism of Heliothis zea and of parasitoid development by 2-tridecanone mediated insect resistance of wild tomato. Journal of Chemical Ecology, Vol. 15, No. 6, (June 1989), pp. 1919-1930, ISSN 0098-0331 
Kaufman, W. C., \& Kennedy, G. G. (1989b). Toxicity of allelochemicals from the wild insectresistant tomato Lycopersicon hirsutum f. glabratum to Campoletis sonorensis, a parasitoid of Helicoverpa zea. Journal of Chemical Ecology, Vol. 15, No. 7, (July 1989), pp. 2051-60, ISSN 0098-0331

Kennedy, G. G. (2003). Tomato, pests, parasitoids, and predators: tritrophic interactions involving the genus Lycopersicon. Annual Review of Entomology, Vol. 48, pp. 51-72, ISSN 0066-4170

Kennedy, G. G., \& Sorenson, C. F. (1985). Role of glandular trichomes in the resistance of Lycopersicon hirsutum $f$. glabratum to Colorado potato beetle (Coleoptera: Chrysomelidae). Journal of Economic Entomology, Vol. 78, No. 3, (June 1985), pp. 547551, ISSN 0022-0493

Kennedy, G. G., \& Barbour, J. D. (1992). Resistance Variation in Natural and Managed Systems, In: Plant Resistance to Herbivores and Pathogens: Ecology, Evolution, and Genetics, R. S. Fritz \& E. L. Simms (Eds.), pp. 13-41, University of Chicago Press, ISBN 0226265536, Chicago, Illinois, USA

Knutson, L. (1981). Symbiosis on Biosystematics and Biological Control, In: Biological Control in Crop Production, G. C. Papavizas (Ed.), pp. 61-78, Allanheld, Osmun Publishers, London, UK

Kogan, M. (1998). Integrated pest management: historical perspectives and contemporary developments. Annual Review of Entomology, Vol. 43, pp. 243-270, ISSN 0066-4170

Koul, O., \& Cuperus, G. W. (2007). Ecologically Based Integrated Pest Management. CAB International, ISBN 1845930649, Wallingford, UK

Krischik, V. A., Landmark, A. L., \& Heimpel, G. E. (2007). Soil-applied imidacloprid is translocated to nectar and kills nectar-feeding Anagyrus pseudococci (Girault) (Hymenoptera: Encyrtidae). Environmental Entomology, Vol. 36, No. 5, (October 2007), pp. 1238-1245, ISSN 0046-225X

Kruess, A., \& Tscharntke, T. (1994). Habitat fragmentation, species loss, and biological control. Science, Vol. 264, No. 5165, (10 June 1994), pp. 1581-1584, ISSN 0036-8075

Kytö, M., Niemela, P., \& Larsson, S. (1996). Insects on trees: population and individual response to fertilization. Oikos, Vol. 75, No. 2, (March 1996), pp. 148-159, ISSN 00301299

Landis, D. A., Wratten, S. D., \& Gurr, G. M. (2000). Habitat management to conserve natural enemies of arthropod pests in agriculture. Annual Review of Entomology, Vol. 45, pp. 175-201, ISSN 0066-4170

Levine, E. \& Oloumi-Sadeghi, H. (1991). Management of diabroticite rootworms in corn. Annual Review of Entomology, Vol. 36, 229-255, ISSN 0066-4170

Levine, E., Oloumi-Sadeghi, H., \& Fisher, J. R. (1992). Discovery of multiyear diapause in Illinois and South Dakota northern corn rootworm (Coleoptera: Chrysomelidae) eggs and incidence of the prolonged diapause trait in Illinois. Journal of Economic Entomology, Vol. 85, No. 1, (February 1992), pp. 262-267, ISSN 0022-0493

Levine, E., Spencer, J. L., Isard, S. A., Onstad, D. W., \& Gray, M. E. (2002). Adaptation of the western corn rootworm to crop rotation: evolution of a new strain in response to a management practice. American Entomologist, Vol. 48, No. 2, pp. 94-107, ISSN 10462821 
Marino, P. C., \& Landis, D. A. (1996). Effect of landscape structure on parasitoid diversity and parasitism in agroecosystems. Ecological Applications, Vol. 6, No. 1, (February 1996), pp. 276-284, ISSN 1051-0761

Mathews, C. R., Bottrell, D. G., \& Brown, M. W. (2004). Habitat manipulation of the apple orchard floor to increase ground-dwelling predators and predation of Cydia pomonella (L.) (Lepidoptera: Tortricidae). Biological Control, Vol. 30, No. 2, (June 2004), pp. 265-273, ISSN 1049-9644

Mattson, W. J. (1980). Herbivory in relation to plant nitrogen content. Annual Review of Ecology and Systematics, Vol. 11, pp. 119-161, ISSN 0066-4162

McClure, M. S. (1977). Resurgence of the scale, Fiorinia externa (Homoptera: Diaspididae), on hemlock following insecticide application. Environmental Entomology, Vol. 6, No. 3, (June 1977), pp. 480-484, ISSN 0046-225X

McMurtry, J. A., \& Croft, B. A. (1997). Life-styles of phytoseiid mites and their role in biological control. Annual Review of Entomology, Vol. 42, pp. 291-321, ISSN 0066-4170

Metcalf, R. L. (1989). Insect resistance to insecticides. Pesticide Science, Vol. 26, pp. 333-358, ISSN 0031-613X

Misener, G. C., Boiteau, G., \& McMillan, L. P. (1993). A plastic-lining trenching device for the control of Colorado potato beetle: beetle excluder. American Potato Journal, Vol. 70, No. 12, (December 1993), pp. 903-908, ISSN 0003-0589

Moser, S. E., \& Obrycki, J. J. (2009). Non-target effects of neonicotinoid seed treatments; mortality of coccinellid larvae related to zoophytophagy. Biological Control, Vol. 51, No. 3, (December 2009), pp. 487-492, ISSN 1049-9644

Murdoch, W. W., Chesson, J., \& Chesson, P. L. (1985). Biological control in theory and practice. American Naturalist, Vol. 125, No. 3, (March 1985), pp. 344-366, ISSN 00030147

Murdoch, W. W., \& Briggs, C. J. (1996). Theory for biological control: recent developments. Ecology, Vol. 77, No. 7, (October 1996), pp. 2001-2013, ISSN 0012-9658

National Research Council (NRC). (1996). Ecologically Based Pest Management: New Solutions for a New Century, National Academy Press, ISBN 0309053307, Washington, D.C., USA

Nihoul, P. (1993a). Controlling glasshouse climate influences the interaction between tomato glandular trichome, spider mite and predatory mite. Crop Protection, Vol. 12, No. 6 , (September 1993), pp. 443-447, ISSN 0261-2194

Nihoul, P. (1993b). Do light intensity, temperature and photoperiod affect the entrapment of mites on glandular hairs of cultivated tomatoes? Experimental and Applied Acarology, Vol. 17, No. 9, (September 1993), pp. 709-718, ISSN 0168-8162

Obrycki, J. J., Lewis, L. C., \& Orr, D. B. (1997). Augmentative releases of entomophagous species in annual systems. Biological Control, Vol. 10, No. 1, (September 1997), pp. 30- 36, ISSN 1049-9644

Obrycki, J. J., \& Tauber, M. J. (1984). Natural enemy activity on glandular pubescent potato plants in the greenhouse: an unreliable predictor of effects in the field. Environmental Entomology, Vol. 13, No. 3, (June 1984), pp. 679-83, ISSN 0046-225X

O'Callaghan, M., Glare, T. R., Burgess, E. P. J., \& Malone, L. A. (2005). Effects of plants genetically modified for insect resistance on non-target organisms. Annual Review of Entomology, Vol. 50, pp. 271-292, ISSN 0066-4170 
Papachristos, D. P., \& Milonas, P. G. (2008). Adverse effects of soil applied insecticides on the predatory coccinellid Hippodamia undecimnotata (Coleoptera: Coccinellidae). Biological Control, Vol. 47, No. 1, (October 2008), pp. 77-81, ISSN 1049-9644

Painter, R. H. (1951). Insect Resistance in Crop Plants. The MacMillan Company, New York, New York, USA

Parrella, M. P., Heinz, K. M., \& Nunney, L. (1992). Biological control through augmentative releases of natural enemies: a strategy whose time has come. American Entomologist, Vol. 38, No. 3, pp. 172-179, ISSN 1046-2821

Patt, J. M., Hamilton, G. C., \& Lashomb, J. H. (1997). Foraging success of parasitoid wasps on flowers: interplay of insect morphology, floral architecture and searching behavior. Entomologia Experimentalis et Applicata, Vol. 83, No. 1, (April 1997), pp. 2130, ISSN 0013-8703

Penman, D. R., \& Chapman, R. B. (1983). Fenvalerate-induced distributional imbalances of 2spotted spider-mite on bean plants. Entomologia Experimentalis et Applicata, Vol. 33, No. 1, (January 1983), pp. 71-78, ISSN 0013-8703

Penman, D. R., \& Chapman, R. B. (1988). Pesticide-induced mite outbreaks: pyrethroids and spider mites. Experimental and Applied Acarology, Vol. 4, pp. 265-276, ISSN 0168-8162

Pereira, R. M., Walker, W., Pfeister, M., \& Koehler, P. G. (2009). Lethal effects of heat and use of localized heat treatment for control of bed bug infestations. Journal of Economic Entomology, Vol. 102, No. 3, (June 2009), pp. 1182-1188, ISSN 0022-0493

Perkins, J. H., \& Garcia, R. (1999). Social and Economic Factors Affecting Research and Implementation of Biological Control, In: Handbook of Biological Control, T. S. Bellows \& T. W. Fisher (Eds.), pp. 993-1008, Academic Press, ISBN 0122573056, San Diego, California, USA

Pimental, D. (Ed.) (1997). Techniques for Reducing Pesticide Use: Economic and Environmental Benefits. John Wiley and Sons, ISBN 0471968382, Chichester, West Sussex, UK

Potter, D. A. (1986). Urban Landscape Pest Management, In: Advances in Urban Pest Management, G. W. Bennett \& J. M. Owens (Eds.), pp. 219-251, Van Nostrand Reinhold Co., ISBN 0442209606, New York, New York, USA

Pottorff, L. P., \& Panter, K. L. (2009). Integrated pest management and biological control in high tunnel production. HortTechnology, Vol. 19, No. 1, (January-March 2009), pp. 61-65, ISSN 1063-0198

Prokopy, R. J., Cooley, D. R., Autio, W. R., \& Coli, W. M. (1994). Second-level integrated pest management in commercial apple orchards. American Journal of Alternative Agriculture, Vol. 9, No. 4, pp. 148-156, ISSN 0889-1893

Rabb, R. L. (1972). Principles and Concepts of Pest Management, In: Implementing Practical Pest Management Strategies: Proceedings of a National Extension Pest Management Workshop, pp. 6-29, Purdue University, West Lafayette, Indiana, USA

Rabb, R. L., Stinner, R. E., \& van den Bosch, R. (1976). Conservation and Augmentation of Natural Enemies, In: Theory and Practice of Biological Control, C. B. Huffaker \& P. S. Messenger (Eds.), pp. 233-254, Academic Press, ISBN 0123603501, New York, New York, USA

Ragsdale, D. W., Landis, D. A., Brodeur, J., Heimpel, G. E., \& Desneux, N. (2011). Ecology and management of the soybean aphid in North America. Annual Review of Entomology, Vol. 56, pp. 375-399, ISSN 0066-4170 
Raupp, M. J., Shrewsbury, P. M., \& Herms, D. A. (2010) Ecology of herbivorous arthropods in urban landscapes. Annual Review of Entomology, Vol. 55, pp. 19-38, ISSN 00664170

Raupp, M. J., Holmes, J. J., Sadof, C., Shrewsbury, P., \& Davidson, J. A. (2001). Effects of cover sprays and residual pesticides on scale insects and natural enemies in urban forests. Journal of Arboriculture, Vol. 27, No. 4, (July 2001), pp. 203-214, ISSN 02785226

Raupp, M. J., Webb, R., Szczepaniec, A., Booth, D., \& Ahern, R. (2004). Incidence, abundance, and severity of mites on hemlocks following applications of imidacloprid. Journal of Arboriculture, Vol. 30, No. 2, (March 2004), pp. 108-13, ISSN 0278-5226

Raynolds, L. T. (2000). Re-embedding global agriculture: the international organic and fair trade movements. Agriculture and Human Values, Vol. 17, No. 3, (September 2007), pp. 297-309, ISSN 0889-048X

Rebek, E. J., \& Sadof, C. S. (2003). Effects of pesticide applications on the euonymus scale (Homoptera: Diaspididae) and its parasitoid, Encarsia citrina (Hymenoptera: Aphelinidae). Journal of Economic Entomology, Vol. 96, No. 2, (April 2003), pp. 446452, ISSN 0022-0493

Rebek, E. J., Sadof, C. S., \& Hanks, L. M. (2005). Manipulating the abundance of natural enemies in ornamental landscapes with floral resource plants. Biological Control, Vol. 33, No. 2, (May 2005), pp. 203-216, ISSN 1049-9644

Rebek, E. J., Sadof, C. S., \& Hanks, L. M. (2006). Influence of floral resource plants on control of an armored scale pest by the parasitoid Encarsia citrina (Craw.) (Hymenoptera: Aphelinidae). Biological Control, Vol. 37, No. 3, (June 2006), pp. 320-328, ISSN 10499644

Rekika, D., Stewart, K. A., Boivin, G., \& Jenni, S. (2008). Reduction of insect damage in radish with floating row covers. International Journal of Vegetable Science, Vol. 14, No. 2, pp. 177-193, ISSN 1931-5260

Ridgway, R. L. (Ed.) (1998). Mass-Reared Natural Enemies: Application, Regulation, and Needs. Thomas Say Publications in Entomology: Proceedings. Entomological Society of America, ISBN 0938522663, Lanham, Maryland, USA

Rieux, R., Simon, S., \& Defrance, H. (1999). Role of hedgerows and ground cover management on arthropod populations in pear orchards. Agriculture, Ecosystems and Environment, Vol. 73, No. 2, (April 1999), pp. 119-127, ISSN 0167-8809

Rhainds, M., Kovach, J., Dosa, E. L., \& English-Loeb, G., (2001). Impact of reflective mulch on yield of strawberry plants and incidence of damage by tarnished plant bug (Heteroptera: Miridae). Journal of Economic Entomology, Vol. 94, No. 6, (December 2001), pp. 1477-1484, ISSN 0022-0493

Roland, J., \& Taylor, P. (1997). Insect parasitoid species respond to forest structure at different spatial scales. Nature, Vol. 386, No. 6626, (17 April 1997), pp. 710-713, ISSN 0028-0836

Royer, T. A., Mulder, P. G., \& Cuperus, G. W. (1999). Renaming (redefining) integrated pest management: fumble, pass, or play? American Entomologist, Vol. 45, No. 3, pp. 136139, ISSN 1046-2821

Sadof, C. S., O’Neil, R. J., Heraux, F. M., \& Wiedenmann, R. N. (2004). Reducing insecticide use in home gardens: effects of training and volunteer research on adoption of 
biological control. HortTechnology, Vol. 14, No. 1, (January-March 2004), pp. 149154, ISSN 1063-0198

Sanford, K. H. (1967). The influence of spray programs on the fauna of apple orchards in Nova Scotia. XVII. Effects on some predaceous mites. Canadian Entomologist, Vol. 99, pp. 197-201, ISSN 0008-347X

Sclar, D. C., Gerace, D., \& Cranshaw, W. S. (1998). Observations of population increase and injury by spider mites (Acari: Tetranychidae) on ornamental plants treated with imidacloprid. Journal of Economic Entomology, Vol. 91, No. 1, (February 1998), pp. 250-255, ISSN 0022-0493

Shelton, A. M., Zhao, J. Z., \& Roush, R. T. (2002). Economic, ecological, food safety, and social consequences of the deployment of Bt transgenic plants. Annual Review of Entomology, Vol. 47, pp. 845-881, ISSN 0066-4170

Simmons, A. T., \& Gurr, G. M. (2005). Trichomes of Lycopersicon species and their hybrids: effects on pests and natural enemies. Agricultural and Forest Entomology, Vol. 7, No. 4, (November 2004), pp. 265-276, ISSN 1461-9555

Smith, H. S. (1919). On some phases of insect control by the biological method. Journal of Economic Entomology, Vol. 12, No. 4, (August 1919), pp. 288-292, ISSN $0022-0493$

Smith, S. F., \& Krischik, V. A. (1999). Effects of systemic imidacloprid on Coleomegilla maculata (Coleoptera: Coccinellidae). Environmental Entomology, Vol. 28, No. 6, (December 1999), pp. 1189-95, ISSN 0046-225X

Snodgrass, G. L., \& Stadelbacher, E. A. (1989). Effect of different grass and legume combinations on spider (Araneae) and ground beetle (Coleoptera: Carabidae) populations in roadside habitats in the Mississippi Delta. Environmental Entomology, Vol. 18, No. 4, (August 1989), pp. 575-581, ISSN 0046-225X

Spencer, J. L., Hibbard, B. E., Moeser, J., \& Onstad, D. W. (2009). Behaviour and ecology of the western corn rootworm (Diabrotica virgifera virgifera LeConte). Agricultural and Forest Entomology, Vol. 11, No. 1, (February 2009), pp. 9-27, ISSN 1461-9555

Spencer, J. L., \& Levine, E. (2008). Resistance to Crop Rotation, In: Insect Resistance Management: Biology, Economics and Prediction, D. W. Onstad (Ed.), pp. 153-183, Academic Press, ISBN 9780123738585, New York, New York, USA

Stern, V. M., Smith, R. F., van den Bosch, R., \& Hagen, K. S. (1959). The integration of chemical and biological control of the spotted alfalfa aphid. I. The integrated control concept. Hilgardia, Vol. 29, pp. 81-101, ISSN 0073-2230

Szczepaniec, A., Creary, S. F., Laskowski, K. L., Nyrop, J. P., \& Raupp, M. J. (2011). Neonicotinoid insecticide imidacloprid causes outbreaks of spider mites on elm trees in urban landscapes. PLoS ONE, Vol. 6, No. 5, e20018. doi:10.1371/journal.pone.0020018, ISSN 1932-6203

Theriault, F., Sequin, P., \& Stewart, K. A. (2009). Incidence of Pieris rapae in organic broccoli grown with living mulches under floating row cover. International Journal of Vegetable Science, Vol. 15, No. 3, pp. 218-225, ISSN 1931-5260

Tooker, J. F., \& Hanks, L. M. (2000). Influence of plant community structure on natural enemies of pine needle scale (Homoptera: Diaspididae) in urban landscapes, Environmental Entomology, Vol. 29, No. 6, (December 2000), pp. 1305-1311, ISSN 0046-225X 
United States Department of Agriculture, Animal and Plant Health Inspection Service (8 July, 2011). Biological Control Program, 03.08.11, Available from http://www.aphis.usda.gov/plant_health/plant_pest_info/biocontrol

van Driesche, R. G., \& Bellows, T. S. (1996). Biological Control. Chapman \& Hall, ISBN 0412028611, New York, New York, USA

van Driesche, R. G., \& Heinz, K.M. (2004). An Overview of Biological Control in Protected Culture, In: Biocontrol in Protected Culture, K. M. Heinz, R. G. Van Driesche, \& M. Parrella (Eds.), pp. 1-24, Ball Publishing, ISBN 1883052394, Batavia, IL, USA

van Haren, R. J. F., Steenhuis, M. M., Sabelis, M. W., \& de Ponti, O. M. B. (1987). Tomato stem trichomes and dispersal success of Phytoseiulus persimilis relative to its prey Tetranychus urticae. Experimental and Applied Acarology, Vol. 3, pp. 115-121, ISSN 0168-8162

van Lenteren, J. C. (1980). Evaluation of control capabilities of natural enemies: does art have to become science? Netherlands Journal of Zoology, Vol. 30, pp. 369-381, ISSN 0028-2960

van Lenteren, J. C., Hua, L. Z., Kamerman, J. W., \& Xu, R. (1995). The parasite-host relationship between Encarsia formosa (Hymenoptera: Aphelinidae) and Trialeurodes vaporariorum (Homoptera: Aleyrodidae). XXVI. Leaf hairs reduce the capacity of Encarsia to control greenhouse whitefly on cucumber. Journal of Applied Entomology, Vol. 119, No. 1-5, (January/December 1995), pp. 553-559, ISSN 0931-2048

Vincent, C., Hallman, G., Panneton, B, \& Fleurat-Lessard, F. (2003). Management of agricultural insects with physical control methods. Annual Review of Entomology, Vol. 48, pp. 261-281, ISSN 0066-4170

Vincent, C., Weintraub, P., \& Hallman, G. (2009). Physical Control of Insect Pests, In: Encyclopedia of Insects (2nd edition), V. H. Resh \& R. T. Cardé (Eds.), pp. 794-798, Academic Press, ISBN 9780123741448, San Diego, California, USA

Wäckers, F. L. (2004). Assessing the suitability of flowering herbs as parasitoid food sources: flower attractiveness and nectar accessibility. Biological Control, Vol. 29, No. 3, (March 2004), pp. 307-314, ISSN 1049-9644

Ware, G. W., \& Whitacre, D. M. (2004). The Pesticide Book (6th edition), MeisterPro, Willoughby, Ohio, USA

Weber, D. C., Ferro, D. N., Buonaccorsi, J., \& Hazzard, R. V. (1994). Disrupting spring colonization of Colorado potato beetle to nonrotated potato fields. Entomologia Experimentalis et Applicata, Vol. 73, No. 1, (October 1994), pp. 39-50, ISSN 0013-8703

Wong, S. W., \& Chapman, R. B. (1979). Toxicity of synthetic pyrethroid insecticides to predaceous phytoseiid mites and their prey. Australian Journal of Agricultural Research, Vol. 30, No. 3, pp. 497-501, ISSN 0004-9409

Zalom, F. (1997). IPM Practices for Reducing Insecticide Use in U.S. Fruit Crops, In: Techniques for Reducing Pesticide Use: Economic and Environmental Benefits, D. Pimental (Ed.), pp. 317-342, John Wiley and Sons, ISBN 0471968382, Chichester, West Sussex, UK 


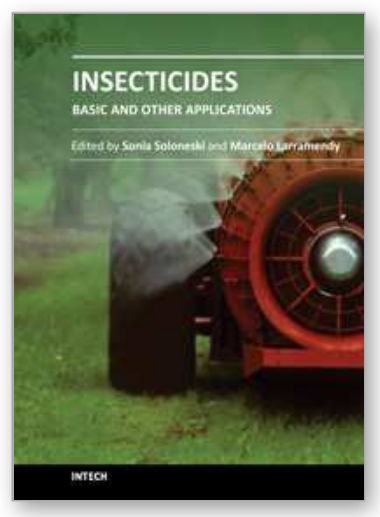

\author{
Insecticides - Basic and Other Applications \\ Edited by Dr. Sonia Soloneski
}

ISBN 978-953-51-0007-2

Hard cover, 268 pages

Publisher InTech

Published online 08, February, 2012

Published in print edition February, 2012

It is our hope that this book will be of interest and use not only to scientists, but also to the food-producing industry, governments, politicians and consumers as well. If we are able to stimulate this interest, albeit in a small way, we have achieved our goal.

\title{
How to reference
}

In order to correctly reference this scholarly work, feel free to copy and paste the following:

Eric J. Rebek, Steven D. Frank, Tom A. Royer and Carlos E. Bográn (2012). Alternatives to Chemical Control of Insect Pests, Insecticides - Basic and Other Applications, Dr. Sonia Soloneski (Ed.), ISBN: 978-953-510007-2, InTech, Available from: http://www.intechopen.com/books/insecticides-basic-and-otherapplications/alternatives-to-chemical-control-of-insect-pests

\section{INTECH}

open science | open minds

\section{InTech Europe}

University Campus STeP Ri

Slavka Krautzeka 83/A

51000 Rijeka, Croatia

Phone: +385 (51) 770447

Fax: +385 (51) 686166

www.intechopen.com

\section{InTech China}

Unit 405, Office Block, Hotel Equatorial Shanghai

No.65, Yan An Road (West), Shanghai, 200040, China

中国上海市延安西路65号上海国际贵都大饭店办公楼405单元

Phone: +86-21-62489820

Fax: $+86-21-62489821$ 
(C) 2012 The Author(s). Licensee IntechOpen. This is an open access article distributed under the terms of the Creative Commons Attribution 3.0 License, which permits unrestricted use, distribution, and reproduction in any medium, provided the original work is properly cited. 